\title{
ADDITIONAL PROVISIONS TO ADMINISTRATIVE ACTS
}

Purpose. Preconditions for the enactment of an administrative act and the legal effects following from enactment of such an act are not always absolutely clear. The reason is life's diversity and the related fact that in life it is impossible to plan everything in advance, therefore, it is also impossible to regulate each detail by law. In this context, there is the need to have certain flexibility in issues connected with the application of legal regulations (as part of the regulatory scope) and their impact (as part of the legal effects of the regulation).

Methods. As concerns the regulatory scope, this is implemented by the use of indeterminate legal concepts (assessment). But in turn, the concepts shouldn't breach the principle of the rule of law, and, at the same time, they must be clearly stated. In practice, this is achieved mainly through specifications by a long-term judicial practice which determines the relevant administrative practice.

Results. As concerns legal effects, there are regulations providing for discretion and therefore ensuring the possibility for the administrative authority to select the appropriate addressee and means of action. In this context, the administrative authority may also choose whether or not to publish an administrative act with an additional provision. Such additional provisions include determination of the terms, conditions, instruction, a clause on revocability and clause on imposition or modification of an obligation. If the administrative act is published at the discretion of the executive authority, then the act may be extended by additional provisions at the appropriate discretion of the executive body. If the administrative act is not issued under the discretion of the executive body, additional provisions may be added if it is definitely permitted by law or if the additional provision is required only for ensuring the fulfillment of the legal preconditions for the enactment of an administrative act.

Conclusions. The article covers the nature and preconditions for enacting additional provisions in administrative law.

Key words: administrative act, discretion, indeterminate legal concepts, condition, determination of terms, instruction, additional provision. 


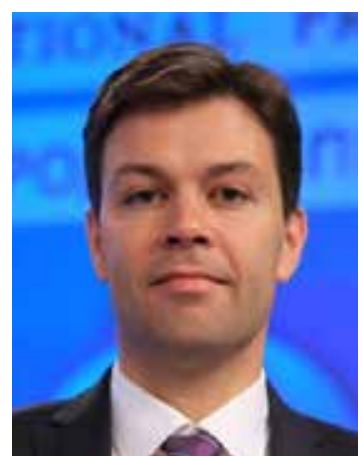

Jörg Pudelka, GIZ Country Director of Kazakhstan, Judge at the Administrative Court of Berlin (Germany) joerg.pudelka@giz.de
In the practice of executive authorities, it is often issued administrative acts containing not only one (main) provision of a regulatory nature, for example, a permit. Frequently additional provisions are issued, for example, a provision that the permission for a public catering enterprise is issued on the condition that five additional water closets will be built for guests. This kind of instructions of executive authority along with the main provision is so-called additional provisions which are divided into "real" and "unreal". § 36 part 2 of Federal Administrative Procedure Act (hereinafter referred to as APA) controls "real" additional provisions. According to this section, there is a determination of term, condition, a provision on revocability, instruction, and a clause on imposition or modification of an obligation.

At the same time, there are other alternatives where the executive body independently modifies the main provision. Such provisions are often also defined as "unreal" additional provisions, although, they do not actually operate along with the main provision but deal with its content. Thus, relevant effects mainly follow in the procedural context if it is referred to the re-examination of this kind of unreal additional provisions.

As a rule, the citizen has the right to demand to issue an administrative act, that is its issuance is not under the discretion of the executive authority, which may contain an additional provision if only such additional provision is allowed by the law or if its purpose is to ensure compliance with the preconditions of the administrative act stipulated in the law ( $\$ 36$ part 1 of APA).

Example: If the applicant has fulfilled all preconditions for issuing a permit for a catering company, then the permit must be issued to him/her. Executive authority doesn't have any context for coercion. However, if almost all preconditions are fulfilled and if, for example, there is a lack of water closets (in Germany, the law indicates the number of toilet rooms per square meter of guests' service area that have to be available), then the executive body can issue a permit with the condition precedent ( 336 p. 2 para. 2 of APA) that the relevant water closets will be set up. This is effective: a citizen gets his/her permission which becomes "valid" only when the toilets rooms are fixed, that is when legal preconditions for issuing permission are executed. However, after installing the sanitary facilities, he/she doesn't need to turn to the executive body again. But if he/she does not build sanitary facilities, the permission will not become "valid". Thus, both private and public interests are satisfied. 
a) Determination of time limits

In accordance with $\S 36$ part 2 of paragraph 1 of APA, if a term is established, it is referred to a provision whereby the effect of any benefit or any charge takes effect, terminates at a certain point or operates during a particular period of time.

Example: Permit to conduct entrepreneurial activities is issued for the period from January 1, 2015, to December 31, 2017.

In order to insert an additional provision in the form of the determination of a time limit, it does not matter whether the relevant point in time has been already determined by the calendar at the moment of issuance of the administrative act. Thus, it is enough that the determinacy becomes due later. However, the determinacy must be predictable. If there are doubts that the time of the event, the determinacy depends on, takes place, then the case is not about the determination of time limits but about the condition.

Example: The permission for a concession stand at the annual spring market may be not determined in the calendar context at the moment of its issuance that is with regard to dates. Nevertheless, it is clear that the market takes place every year in spring that is it's about the determination of date even if the exact market days are identified later (Kopp, Ramsauer, 2015).

Another typical example of term determination is stay permit for foreigners (for example, visas).

b) Condition

In terms of $\S 36$ part 2 of APA, a condition is a provision whereby validation or termination of benefit or charge depends on the indefinite term of the future event.

It is necessary to distinguish two possible scenarios: suspensive condition and resolutive condition. In contrast with term determination, in the case of effect (suspensive condition) or termination (resolutive condition) of the regulatory provision followed by this administrative act depends on event occurrence which has not been completely undefined at the moment of the issuance of the administrative act.

Example: A foreigner gets a residence permit in Germany exclusively for the period of work for a specific employer (for example, a fine cuisine chef at a specialised restaurant). From the date of termination of the employment contract, the resolutive condition comes into effect and thus, the stay permit automatically terminates (OVC, 1966).

The applicant gets a construction permit under the condition that prior to the building activities and related felling of trees on the construction site, so he/she is obliged to plant the appropriate number of trees on another piece of land. When the trees have been planted on another piece of land, a suspensive condition comes into effect, and the applicant can use the construction permit. The example may be modified by setting instruction due to which the executive body, on the one hand, seeks to have an opportunity for implementing the provision on tree planting and, on the other hand, doesn't want that construction start depends on planting process (condition of processing particular case).

c) Clause on revocability

The clause on revocability provides the executive body with authority, under specific circumstances stipulated by the administrative act or by the legislation or in accordance with the general principles acting towards the competent exercise of discretion, to revoke the administrative act to which the clause on full or partial revocability is attached in 
accordance with $\S 49$ part 2 of paragraph 1 or in accordance with the relevant rules of law and, thus, to terminate it in regard to the future (Kopp, Ramsauer, 2015).

In such a case, revocation is a new administrative act which can be independently appealed by virtue of legal remedies (response and claim). This new administrative act may not only cancel the former act (except as otherwise provided herein, however, this is possible exclusively in regard to the future) but also to supplement it with onerous conditions, that is, with other additional provisions.

A special type of revocability clause is the so-called amendment clause. If at the moment of issuance of the administrative act there are doubts towards, for example, an amount of particular payment, the executive authority can provide it with later amendment clause. In such case, the amendment also may take place with retroactive effect due to which the former administrative act (at least partially) can be cancelled.

d) Instruction

According to $\S 36$ part 2 paragraph 4 of APA, an instruction is a provision by virtue of which the beneficiary (that is, the addressee of the administrative act) is enacted with commitment, undergoing and failure of certain actions.

In the context of instructions, this is about independent regulatory provision which is in parallel with regulatory provision of the main administrative act. Although the instruction refers to the act, however, it is independent of it by the content in the sense that the basic administrative act can exist without the regulatory provision of the instruction. If it doesn't, then this is not about a "real" instruction, but about something else (Latin aliud), a substitution. In such cases, this is the so-called determination.

Example: If the applicant filed for a permit to build a house with a pointed roof but got a construction permit related to an "instruction" to build a house with a flat roof, this is not an instruction in the context of $\S 36$ part 2 of paragraph 4 of APA. The "instruction for a flat roof" is not an independent provision; on the contrary, it directly regulates the content of the main administrative act (construction permit). "The instruction for a flat roof" cannot be imaginatively excluded in such a way that the main administrative act keeps its relevance. The applicant filed for a permit to build a house with a pointed roof but he/she got a "substitution", something completely different ("aliud") (so-called "modified instruction"). On a related note, this - unsolicited - permit to build the house with a flat roof is also formally illegal as there is a lack of required application for the construction. However, this formal mistake can be improved by the fact that the applicant uses construction permit and thereby implicitly submits backdating application.

Within this framework, when differentiating instruction and determination, it is necessary to put a question whether the instruction contains an independent regulatory provision which falls beyond the regulatory provision of the main administrative act and has an independent regulatory content, which, if it is necessary, can also be implemented by compulsory enforcement.

Example: If the applicant has received the required permission to build a supermarket, however, it is connected with an instruction to provide cars with appropriate parking spaces, and then this is an independent - separated from the permit for supermarket construction - regulatory provision, that is, a "real" instruction. This instruction also may be independently put into effect. The executive authority could produce parking spaces 
by fulfilling this obligation at the developer's expense in the case of failure to fulfill its duties. However, it does not affect either the existence or the validity of the permission to build a supermarket in no way.

Sometimes there are problems with the distinction between instruction and condition. In the above example, one could also think that the executive body wanted to make the creation of parking spaces a condition for the construction of a supermarket. For this differentiation, it is possible to refer to the classical formula of Friedrich Carl von Savigny, the Prussian jurist and the former Minister of Lawmaking of Prussia. In 1840 he noted in his paper "System of modern Roman law" ("Das System des heutigen römischen Rechts"):

A condition suspends but does not enforce;

an instruction enforces but does not suspend (Friedrich Carl von Savigny, 1840).

In addition, Savigny makes a differentiation in the content. If the executive body seeks to achieve the possibility of independent implementation (execution) of "instruction" but that it does not affect the validity of the basic administrative act, then the instruction is accepted. If the executive body, on the contrary, seeks to be able to put into effect not the additional provision but a combination under which the basic provision can be used only after the condition fulfillment, then it refers to the condition in the context of $\S 36$ part 2 of paragraph 2 of APA. Within this framework, in the above example, one may speak about the instruction in the context of $\S 36$ part 2 of paragraph 2 of APA as it is not important for the executive body that parking spaces be build up for a non-existent supermarket. In fact, one can proceed from the fact that parking spaces will be built together with a supermarket, and, if they do not available or there is a lack, the executive authority may also require fulfilling the duty of creating parking spaces by compulsory execution.

e) Clause on imposition and modification of instruction

The clause on imposition and modification of an instruction empowers the executive body to adopt or amend the instruction after the issuance of the main administrative act according to $\S 36$ part 2 of paragraph 5 of APA. Hence, the clause also permits the executive body tightening instructions after the issuance of an administrative act.

A precondition for the clause on instructions is the fact that actual and legal regulation at the moment of issuing of an administrative act, for example, can't be clarified completely, but the executive body did not want to refuse granting the applications for reasons of adequacy. Then, it is provided the opportunity to issue the intended administrative act, however, reserving the right to impose instructions later. But the clause on imposition or modification a prescription cannot be abused in order to provide the executive authority with "complete freedom of action in the future", thereby compensating shortcomings when clarifying facts of the case or during a legal assessment (Kopp, Ramsauer, 2015).

f) Additional provisions

The opportunity of the executive body to issue an administrative act with an additional provision primarily depends on whether the issuance of the main administrative act is under the discretion of the executive authority or there is the right to claim to issue the act. According to $\S 36$ part 1 of APA, an administrative act for the issuance of which there is the right to claim may be issued with an additional provision only if it is allowed 
by a certain norm or if it must ensure the execution of the conditions of the administrative act provided for by law.

This is clear: if a citizen has the right to claim issuance; if the executive body has no discretion regarding the act issuance, then it does not have the right to restrict again the right of the citizen de facto or in a "roundabout" way issuing an administrative act only with an onerous additional provision.

If at the moment of issuing an administrative act, on the contrary, not all the conditions necessary for its issuance have been fulfilled, but the executive body may ensure that they will be fulfilled soon, then the principle of proportionality will be consistent if the executive authority does not refuse to issue the administrative act, which the body will be obliged to issue in the near future in any case and will issue it with an additional provision ensuring compliance with all the preconditions provided by law.

Example: A wants to set up a catering enterprise. However, in the old building, there is no certain number of urinal units and toilets, which is fixed by the Regulation on public catering enterprise for such a large service area. Instead of dismissal of permit, the executive authority may issue a permit with the condition that A will install the missing sanitary facilities. This is the best option for both parties: A immediately gets a permit and it has not to go through the licensing procedure again, the executive authority has not to deal again with this case (operating efficiency of the executive authorities).

However, if an administrative act is issued at the discretion of the executive authority, then, the act may be also a supplementary regulation at the relevant discretion of the executive body (Section 36 Part 2 of APL). This is also quite logical. If the executive body has to decide to issue or not to issue an administrative act at the discretion, taking into account all the facts of a particular case, then there may be several possible options for such kind of a decision: refusal to issue an administrative act, issuance of an administrative act according to the application or - the sort of golden mean - issuance of an administrative act but with (restrictive) supplementary regulation.

The discretion of the executive authority is not "free" but always shall be exercised for the purpose of its provision constantly observing statutory limits of discretion ( $\$ 40$ of APA).

The executive body does not need an individual provision of the law empowering to issue an additional stipulation in the case when the main administrative act is issued at its discretion; in this context, $\S 36$ part 2 of APA covers it. According to the very wording of $\S 36$ part 2 of APA, it follows that $\S 36$ part 1 of APA is (additionally) suitable in the case of discretionary administrative acts.

g) Differentiation and procedural effects

If the distinction between whether it is a matter of an additional provision to any discretionary administrative act or any related administrative act is more important for the issue of the need for an authorizing norm of law, then the issue of differentiation of individual additional provisions from each other is of central procedural importance. The possibility and way of challenging an additional provision depends on the type of additional provision.

The main rule is the fact that a claim challenging act is an appropriate type of claim with regard to onerous administrative acts. Due to it, a claimant - after passing the procedure of pretrial appeal - has an opportunity to seek full or partial cancellation of an admin- 
istrative act by the court. There is no need for special execution or enforcement of a judicial act by the executive authority.

It is beyond argument that this also applies to instructions and clauses on imposition or modification of an instruction ( $\$ 36$ part 2 paras. 4 and 5 of APA) (Kopp, Ramsauer, 2015: 60). The very wording of Article 36 of part 2 of APA indicates that these additional provisions may be a subject of an independent dispute: this norm states that an administrative act may be combined with an order or order's clause. But according to the letter of the article, it is allowable to combine only independent mess. It seems logical that such a combination could be again disconnected by means of a suit. In addition, the instruction contains an independent regulatory stipulation that refers to the regulatory provision of the main administrative act or is interrelated with it. Nevertheless, this order meets all the criteria of administrative act fixed in $\S 35$ of APA. Thus, a claimant may also sue for challenging only in relation to an instruction or a clause on imposition or modification of instruction. In the case of success, the court will cancel an instruction, and the claimant will get the main administrative act without an additional provision.

All other variations cause violent disputes in some degree among representatives of science and practice. The classical doctrine relies upon the fact that all other additional provisions cannot be a subject of independent challenging. According to this point of view, the claimant, if he/she disagrees with the additional provisions, must bring suit on enforcement to fulfill an obligation in the form of issuing the main administrative act without the additional provision. In this regard, a claim cannot be filed for challenging just one additional provision (Kopp, Ramsauer, 2015).

The modern doctrine, which the Federal Administrative Court also joined (Entscheidungen des Bundensverwaltungsgerichts), on the contrary, now relies upon on the fact that all (present) additional provisions, which are provided in $\S 36$ part 2 of APA, may be a subject of an independent contestation. This is supported, firstly, by the resulting clarity and uniformity: there is a single legal protection in respect to all additional revisions. In addition, this point of view is favoured by the consideration that the issue of separation of the main administrative act from the additional provision is not a procedural but a substantive legal matter. If so, then this issue is also should be clarified not by virtue of procedural law (type of a claim) but by virtue of substantive law, more specifically in the context of the validity of the claim. Thus, in accordance with this fact, a claim on contestation is relevant in respect of all types of (real) additional provisions, and it is subjected to clarifying whether the main administrative act can lawfully exist without an additional provision under the framework of justification of the claim. Only in this case the claim is justified. Otherwise, the claim must be refused.

Example: If a permit is issued for a public catering enterprise with the condition that, according to Regulation on public catering enterprises, firstly, it is necessary to set up a certain number of urinal units and toilets, the claimant may file an independent claim to challenge this condition in accordance with a new doctrine. However, within the framework of the validity of the claim, the court will verify whether the main administrative act (permission for catering) can legally exist without this condition. If it doesn't (as in this case) the claim on contestation will not be satisfied even if the condition is unlawful and violates the rights of the claimant. 
In other words, procedurally there will be no more difference which of the (real) additional provisions provided in $\S 36$ of part 2 of APA are in the process. Claim on contestation is always appropriate. In the context of justifiability, it is necessary to check the followings:

1) the availability of an authorizing provision of law for encumbrance (in this case it includes exclusively encumbrance resulting from an additional provision);

2) pro forma legitimacy of an additional provision;

3) substantive legitimacy of an additional provision (does the additional provision fulfill all the preconditions of the authorizing rule of law?);

4) separable nature (herein, it is verified whether the main administrative act could legitimately exist without an additional provision);

5) violation of claimant's rights.

If all preconditions are available, the claim is justified. If at least one precondition is not fulfilled (for example, separable nature), then it is necessary to dismiss the claim. It is essential to emphasize another practical consequence of the fact that a claim on contestation is appropriate in all cases: an individual claim on contestation under additional provision leads to its suspension according to the rules of $\S 80$ of the Administrative Procedure Code (with provided exceptions).

In the case of availability of so-called unreal additional provisions, that is, those that are not enlisted in $\S 36$ part 2 of APA (for example, "unreal" or modified instruction), but nevertheless there is a rule that an independent claim on contestation in relation to (unreal) additional provision is impossible. In such a case, the claimant has the possibility to fill a claim for enforcement in the form of issuing the desired administrative act.

And there is no another alternative as an unreal instruction does not have - including in procedural terms - any part that can be separated from the basic provision. It independently modifies the main provision and as a result, is not an additional (new) provision but just a constituent part of the main provision. Accordingly, the means of challenging should also be directed to the main provision. However, taking into account the fact that it rarely makes sense for a complainant to dispute the main regulation, and in the case of a modified instruction, as a rule, this means the necessity of filing a claim on coercion to fulfill the obligations in the form of issuing an act.

Example: A applies for a permit to build a house with a pointed roof. A is allowed to build a house with an "instruction" to build a flat roof instead of a pointed one. This unreal instruction or a modified instruction is not an additional instruction in the context of $\S 36$ part 2 of APA because it has no independent regulatory content. On the contrary, it refers to the content of the main provision, thus, there is only one regulatory provision, namely, the provision of the main administrative act. Under this framework, (unreal) additional instruction also cannot be disputed separately by virtue of a claim on contestation. A has to fill a claim on coercion to fulfill the obligation in the form of issuing a permit to build a house with a pointed roof.

Consequently, if the executive body doesn't issue an administrative act, which was requested by the citizen in his/her application, with some restrictive additional regulation but issues a "substitution" that is "something else" ("aliud"), then the citizen has to fill a claim on coercion to exercise the obligation in the form of issuing the desired adminis- 
trative act. Thus, there is nothing to dispute separately: otherwise, in our example, after challenging "instruction for a flat roof", the applicant would have the permission to build a house without a roof because the unreal instruction modified the content of the construction permit regarding roof and did not add a second roof to the first one, which also could be removed.

\title{
Bibliography:
}

1. Kopp F.O., Ramsauer U. Verwaltungsverfahrensgesetz : VwVfG. Kommentar. München : C.H. Beck, 2015. 1899 S.

2. Oberverwaltungsgericht Rheinland-Pfalz hat seinen Sitz in Koblenz. DÖV. 1966. № 209.

3. Savigny F.C. von. System des heutigen römischen Rechts. Berlin : Veit, 1840. $473 \mathrm{~S}$.

4. Entscheidungen des Bundesverwaltungsgerichts (BVerwGE) / hrsg. von Mitgliedern des Gerichts. Köln : Carl Heymanns Verlag, 1991. 500 S.

\section{References:}

1. Kopp, F.O., Ramsauer, U. (2015). Verwaltungsverfahrensgesetz: VwVfG. Kommentar [Administrative Procedure Act: VwVfG. comment]. München: C.H. Beck [in German].

2. OVG (1966). Oberverwaltungsgericht Rheinland-Pfalz hat seinen Sitz in Koblenz [Higher Administrative Court Rhineland-Palatinate is located in Koblenz]. DÖV, no. 209 [in German]

3. Savigny, F.C. von. (1840). System des heutigen römischen Rechts [System of today's Roman law]. Berlin: Veit [in German].

4. Mitgliedern des Gerichts (1991). Entscheidungen des Bundesverwaltungsgerichts (BVerwGE) [Decisions of the Federal Administrative Court (BVerwGE)]. Köln: Carl Heymanns Verlag [in German].

\section{ДОДАТКОВІ ПОЛОЖЕННЯ ДО АДМІНІСТРАТИВНИХ АКТІВ}

\author{
Йорг Пуделька, \\ голова представництва \\ Німецького товариства з міжнародного співробітництва (GIZ) у Казахстані, \\ суддя Адміністративного суду м. Берліна (Німеччина) \\ joerg.pudelka@giz.de
}

Мета. Передумови для прийняття адміністративного акта та правові наслідки, щчо постають із прийняття такого акта, не завжди є абсолютно зрозумілими. Причина полягає в різноманітності життя та пов'язується з тим, що в житті неможливо спланувати все заздалегідь, а отже, закон не може регулювати кожну деталь. У цььоу контексті є необхідність мати певну гнучкість у питаннях, пов'язаних із застосуванням правових норм (як частини сфери регулювання) та їх впливу (як частини юридичних наслідків регулювання).

Методи. Що стосується сфери регулювання, то воно здійснюється иляхом використання невизначених правових понять (оцінка). Однак поняття у свою чергу не повинні порушувати принцип верховенства права та водночас мають бути чітко визначеними. На практиці ие досягається переважно за допомогою специфікації довгострокової судової практики, яка визначає відповідну адміністративну практику. 
Результати. Якщзо йдеться про юридичні наслідки, то єнормативні акти, які передбачають можливість розсуду, а отже, забезпечують адміністративному органу можливість обрати відповідного адресата та засоби дій. У иььму контексті адміністративний орган може також обирати, чи публікувати адміністративний акт із додатковим положенням. До таких додаткових положень належать визначення термінів та умов, інструкиії, положення про відкликання та положення про накладення чи зміну зобов'язання. Якщо адміністративний акт публікується на розсуд виконавчої влади, то ией акт може бути продовжений додатковими положеннями за належним розсудом виконавчого органу. Якщо адміністративний акт не видається на розсуд виконавчого органу, додаткові положення можуть бути додані, якщс иее чітко визначається законом або якщо додаткове положення необхідне лише для забезпечення виконання правових передумов для прийняття адміністративного акта.

Висновки. Таким чином, у статті розглянуто сутність і передумови для ухвалення додаткових положень в адміністративному праві.

Ключові слова: адміністративний акт, розсуд, невизначені юридичні поняття, умова, визначення термінів, інструкція, додаткове положення. 